\title{
Lessons in developing successful invasive weed control programs
}

\author{
G. L. ANDERSON ${ }^{1}$ ' E. S. DELFOSSE, N. R. SPENCER, C. W. PROSSER, AND R. D. RICHARD
}

Authors are Ecologist, USDA, Agricultural Research Service, Northern Plains Agricultural Research Laboratory, Sidney, Mont. 59270; National Program Leader for Weed Science USDA, ARS, The George Washington Carver Center, Beltsville, Md 20705-5139; Entomologist, USDA, Agricultural Research Service, Plant Protection Research Unit, Ithaca, N.Y. 14853; Ecologist, USDA, Agricultural Research Service, Northern Plains Agricultural Research Laboratory, Sidney, Mont. 59270; and Entomologist, USDA, APHIS, Plant Protection and Quarantine, FSL, MSU, Bozeman, Mont. 59717-0278. ${ }^{1}$ Corresponding author.

Abstract

The development of successful regional or national invasive weed control programs is often hampered by the way the problem is approached. Typically weed control programs are developed and evaluated solely from the perspective of the biological sciences. While this is appropriate from a local or landscape perspective, it will probably not produce the desired results when addressing widespread well-established infestations that impact large regions. The "Ecological Area-wide Management (TEAM) of Leafy Spurge" program was the first U.S. Department of Agriculture (USDA), Agricultural Research Service (ARS) area wide invasive weed program. The 5-year program, funded by the ARS and conducted cooperatively with the USDA Animal and Plant Health Inspection Service, focused on the control of leafy spurge (Euphorbia esula L.) in North Dakota and South Dakota, Montana and Wyoming. Now in its final year (2001), the TEAM Leafy Spurge program has made significant progress in controlling leafy spurge, increasing public awareness of the problem and demonstrating the effectiveness of biologically-based integrated pest management. While this is a significant accomplishment, the lessons learned over the course of the project clearly demonstrate that the success of regional weed control programs depends on more than a persistent, marked reduction in the pest population. Effective regional weed control programs need to focus not only on biological issues, but also on the ecological, scientific, economic, social and legal factors that influence the effectiveness of the program. Therefore, the implementation and subsequent evaluation of a weed control program must include all the principal factors that will ultimately determine success and sustainability. This manuscript outlines the history of leafy spurge on the North American continent, the situation currently facing weed managers, and an evaluation of the TEAM Leafy Spurge program's success for each factor listed above. The final analysis indicates that successful biologically-based leafy spurge control is on the horizon, especially when weed managers understand the number of problem areas that must be addressed to achieve a sustained reduction of a weed population. The amount of time it will take to be realized depends on our commitment to solving the problem and our willingness to work together as a cohesive team.

The authors would like to thank the following individuals and their research teams for contributing the preliminary data presented in this manuscript: Don Kirby, Rod Lym, Jack Butler, Larry Leistritz, Tim Faller, Roger Sheley, Don Mundal, Robert Carlson, David Kazmer, and Robert Nowerski.

Manuscript accepted 4 Mar. 02.

\section{Resumen}

El desarrollo de programas exitosos de control de maleza a nivel nacional o regional es a menudo impedido por la manera en la que se aborda el problema. Los programas de control de maleza son típicamente desarrollados y evaluados solamente desde de la perspectiva de las ciencias biológicas. Mientras esto es adecuado desde una perspectiva local o de paisaje, probablemente no producirá los resultados deseados cuando se abordan infestaciones dispersas bien establecidas que impactan grandes regiones. El programa "Ecological Area-wide Management (TEAM) of Leafy Spurge" fue el primer programa de área extensa de maleza invasiva del Servicio de Investigación Agrícola (ARS) - Departamento de Agricultura de Estados Unidos (USDA). El programa de 5 años fue financiado por el ARS y conducido en forma cooperativa con el Servicio de Inspección de Plantas y Animales del USDA y enfocado al control de "Leafy spurge" (Euphorbia esula L.) en Dakota del Norte, Dakota del Sur, Montana y Wyoming. Ahora en su año final (2001), el programa TEAM "Leafy spruge" ha hecho avances significativos en controlar el "leafy spruge", incrementando la conciencia publica respecto al problema y demostrando la efectividad del manejo integrado de plagas basado en control biológico. Mientras este es un logro significativo, las lecciones aprendidas en el curso del proyecto demostraron claramente que el éxito de programas regionales de control de maleza depende algo mas que una persistente y marcada reducción de la población de la maleza. Los Programas regionales efectivos de control de maleza necesitan enfocarse no solo en los problemas biológicos, sino también en los factores ecológicos, científicos, económicos, sociales y legales que influyen en la efectividad del programa. Por lo tanto, la implementación y evaluación subsecuente de un programa de control de maleza debe incluir todos los factores principales que finalmente determinan el éxito y sostenibilidad. Este manuscrito da una perspectiva de la historia del "leafy spruge" en el continente Norteamericano, la situación que actualmente encaran los manejadores de maleza y una evaluación del éxito del programa "TEAM Leafy Spurge" para cada uno de los factores enlistados arriba. El análisis final indica que el éxito del control del "leafy spruge" con bases biológicas esta en el horizonte, especialmente cuando los manejadores de maleza entienden el número de áreas problema que deben ser abordadas para lograr una reducción sostenida de la población de maleza. La cantidad de tiempo que tomará para ser realizado depende de nuestro compromiso para resolver el problema y nuestra disponibilidad para trabajar juntos como un equipo unido. 
Key Words: biological control, Aphthona, weeds, invasive species, success, integrated pest management

Biological agents have been used to manage problem weed species for more than 100 years (Gassmann 1996). The goal of biological control is to use diseases, parasites, or predators to increase the mortality of the problem weed species, thus reducing the plant's ability to effectively compete with native vegetation (Krebs 1978). The success or failure of biological control programs has typically been evaluated from the perspective of the agent/host interaction. Perhaps the quintessential definition of biological control success is "a persistent, marked reduction in the pest population" (Lawton 1985).

Presently, 9 of the 15 insects approved in the United States for leafy spurge (Euphorbia esula L.) field release have established viable populations. Yet, the best estimates of leafy spurge population change indicate that infestations are doubling every 10 years and in some cases every 5 years (Anderson et al. 1999). Based on Lawton's (1985) definition and the above observations, we conclude that current efforts to control leafy spurgeincluding biological control-have not yet been successful.

Too often our perception of success or failure is predetermined by how we choose to view the problem. The evaluation of biological control success is both time- and scale-sensitive; it is not independent of the knowledge base and infrastructure supporting the program, and it is closely tied to the socioeconomic conditions existing across the region at any given time. Perhaps we are blurring the line between classical biological control and biological control programs; however, the 2 are codependent. The methodology we use to approach a problem is often as important as the biological interaction in determining the success or failure of a program. Certainly our definition of success should not be limited to a biological evaluation of agent/host interactions, especially when viewing the problem on a national or regional scale.

This paper addresses 2 fundamental questions: Has the leafy spurge control program in North America been successful? And if not, what can be done to make it successful? We take a brief look at the history of the problem and expand our understanding of success beyond that of agent/host interactions. Examples from "The Ecological Area-wide Management of Leafy Spurge (TEAM Leafy Spurge)" are presented to expand the concepts presented in this paper. The TEAM Leafy Spurge is a 5-year USDA, Agricultural Research Service (ARS), Area-wide Program funded by the ARS and managed cooperatively with the USDA, Animal and Plant Health Inspection Service.

\section{Historical Context}

Leafy spurge is a deep-rooted perennial weed with erect stems 40 to $80 \mathrm{~cm}$ tall (Stevens 1963). The weed reproduces by both vegetative buds and the production of large quantities of seeds. A native of Eurasia, leafy spurge was first reported in the state of Massachusetts in 1827 (Noble et al. 1979). Several sources can be used to document the historical progression of leafy spurge from Massachusetts into the central United States and Canada (key sources include Dunn 1979, Britton 1921, Quimby and Wendel 1997, Selleck et al. 1962, Galitz 1980, and Bangsund and Leistritz 1991). Table 1 provides a short synopsis of the historical facts concerning leafy spurge and key biological control events. This information helps place the current situation facing weed managers within a historical context. Consider that prior to the year 2000 , leafy spurge had existed in North America for at least 173 years. It took almost 100 years before the plant was identified as a weed. Cultural controls and sterilization of the soil were the primary methods for dealing with leafy spurge prior to the development of effective herbicides (late 1940s and early 1950s). Chemical control quickly became the tool of choice for treating leafy spurge infestations because it was relatively cheap and the effects were almost immediate. Chemical control efforts of the last 50 years certainly have affected the distribution and rate of leafy spurge spread; however, chemical costs have continued to rise and the process has proven to be ineffective in achieving sustained long-term control. Negative environmental impacts have also resulted from the use of non-selective chemicals. Today, leafy spurge is believed to infest 2 million hectares throughout 35 states (Fig. 1) and all the Canadian provinces except Newfoundland (Quimby and Wendel 1997).

The introduction of biological control in the mid-1960s provided another tool for the control of leafy spurge. In the 1960s, the concept of biological control for leafy spurge was in its infancy. Demonstrations were made during symposiums where Hyles euphorbiae (L), commonly known as the "leafy spurge hawk moth larvae" were released into glass containers containing healthy leafy spurge. By the end of the presentation the hawk moth larvae had

\section{Leafy Spurge Distribution}

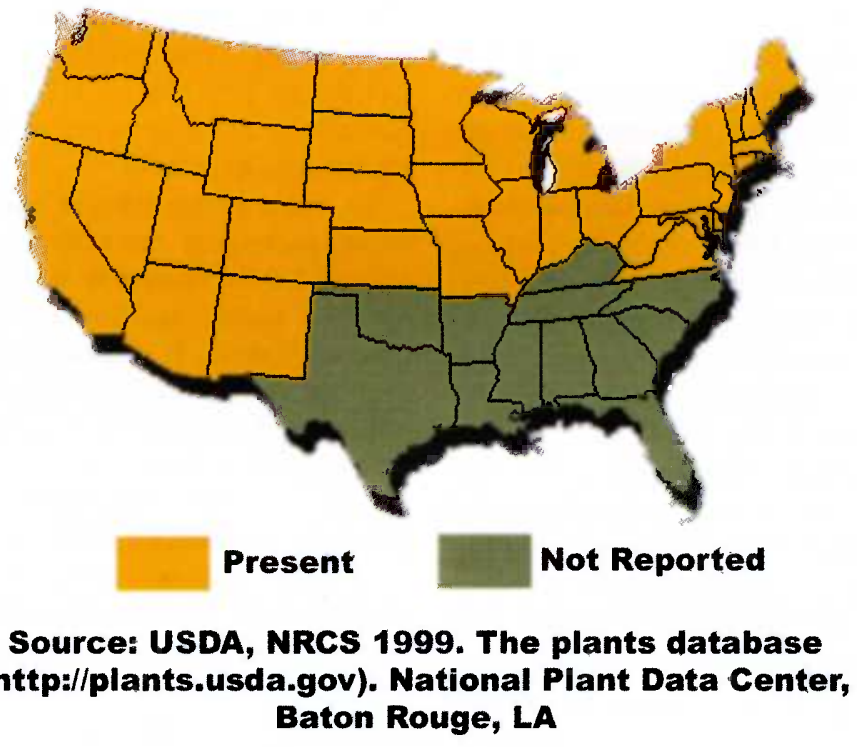

Fig. 1. The 35 states presently impacted by leafy spurge. 
Table 1. Historical progression of leafy spurge and key biological control events.

\begin{tabular}{|c|c|}
\hline Year & Key Event \\
\hline 1827 & Leafy spurge was first documented in Massachusetts. \\
\hline 1876 & The plant was found in New York and identified as a "rare plant." \\
\hline 1913 & Leafy spurge was found in at least four states and Canadian provinces. \\
\hline 1921 & Leafy spurge was first labeled as a "weed" in a New York Herald editorial. \\
\hline 1940 s \& 1950s & New herbicides become available and managers begin to use them on a progressively larger scale. \\
\hline $1960 \mathrm{~s}$ & Efforts to manage leafy spurge with biological control begin. \\
\hline 1964 & The first leafy spurge biocontrol agent (Hyles hawk moth) is released. \\
\hline 1970 & Leafy spurge occupies 26 states. \\
\hline 1979 & $\begin{array}{l}\text { The first leafy spurge symposium was held and participants begin to develop today's local, state and federal leafy spurge management } \\
\text { programs. }\end{array}$ \\
\hline 1985 & The first Aphthona flea beetle (A. flava) was released. \\
\hline 1988 & The USDA-Animal and Plant Health Inspection Service (APHIS) began their leafy spurge biological control program. \\
\hline 1989 & Aphthona nigriscutis was approved and released. \\
\hline 1990 & Researchers determine that leafy spurge infestations double in area every 10 years. \\
\hline 1991 & $\begin{array}{l}\text { Agricultural economists at North Dakota State University estimate direct and indirect economic impacts of leafy spurge at } \$ 144 \text { million for } \\
\text { North and South Dakota, Montana and Wyoming. }\end{array}$ \\
\hline 1993 & Aphthona lacertosa is approved and released. \\
\hline 1994 & Leafy spurge is estimated to infest 650,000 hectares in North and South Dakota, Montana and Wyoming. \\
\hline 1997 & $\begin{array}{l}\text { Natural Resources Conservation Service reports the presence of leafy spurge in } 35 \text { states; the heaviest populations occur in North and South } \\
\text { Dakota, Montana, Minnesota, Nebraska, Colorado, Idaho and Wyoming. }\end{array}$ \\
\hline
\end{tabular}

devoured the leafy spurge stems and leaves. This type of showmanship excited the leafy spurge control community and the search for additional leafy spurge biological control agents was expanded. Unfortunately for Hyles, like so many "prototypes" before it, the species was not destined to become the workhorse of the biological control program. Disease problems prevented Hyles from developing population levels substantial enough to impact leafy spurge populations. But the potential demonstrated by the hawk moth energized the search for other biological control agents. Table 2 lists the 15 leafy spurge biological control agents currently approved in the United States for field release on leafy spurge. Presently, 9 of the 15 insects have established; however, control of leafy spurge on a local level within specific habitats has been achieved primarily by Aphthona nigriscutis (Fondras) and A. lacertosa (Rosenhauer) / czwalinae (Weise) (Fig. 2). The other 6 biological control agents that have established in the
United States and Canada have enjoyed less success than these 3 Aphthona species, however, limited populations are present over large areas dominated by leafy spurge. What role these "lesser" control agents will play as leafy spurge control efforts decrease weed population levels remains to be seen.

So, what is the state of the ecosystem weed managers have to contend with today? Leafy spurge is well established (greater than 2 million hectares in the United States). It displaces most native vegetation, including threatened and endangered species (Sterling et al. 2000) and impacts native ungulates (Trammell and Butler 1995). The deep roots of the plant, along with its ability to reproduce and spread both by vegetative buds and seeds, enable the population to double in size every 10 years or less (Anderson et al. 1999). Chemical control has not produced sustained long-term control, and inappropriate chemical use has caused negative impacts to other components of the envi- ronment. Cultural control methods such as sheep and goat grazing are not widely accepted as viable control alternatives. Conversely, the acceptance of biological control has increased. Nowierski (1985) attributed the increased acceptance and use of biological control to reduced economic and ecological costs during a period of depressed agronomic income and heightened environmental awareness. Aphthona flea beetles have demonstrated the greatest amount of success in controlling leafy spurge populations within specific habitats; however, determining the number of hectares the flea beetles have controlled is more elusive than estimating the amount of leafy spurge in North America. While the overall rate of leafy spurge establishment is still likely greater than the rate of control, the populations of biological control agents are also increasing rapidly. It is very difficult to find leafy spurge stands in western North Dakota that do not have a resident population of Aphthona flea beetles (Personal Communication, Donald Kirby, June 

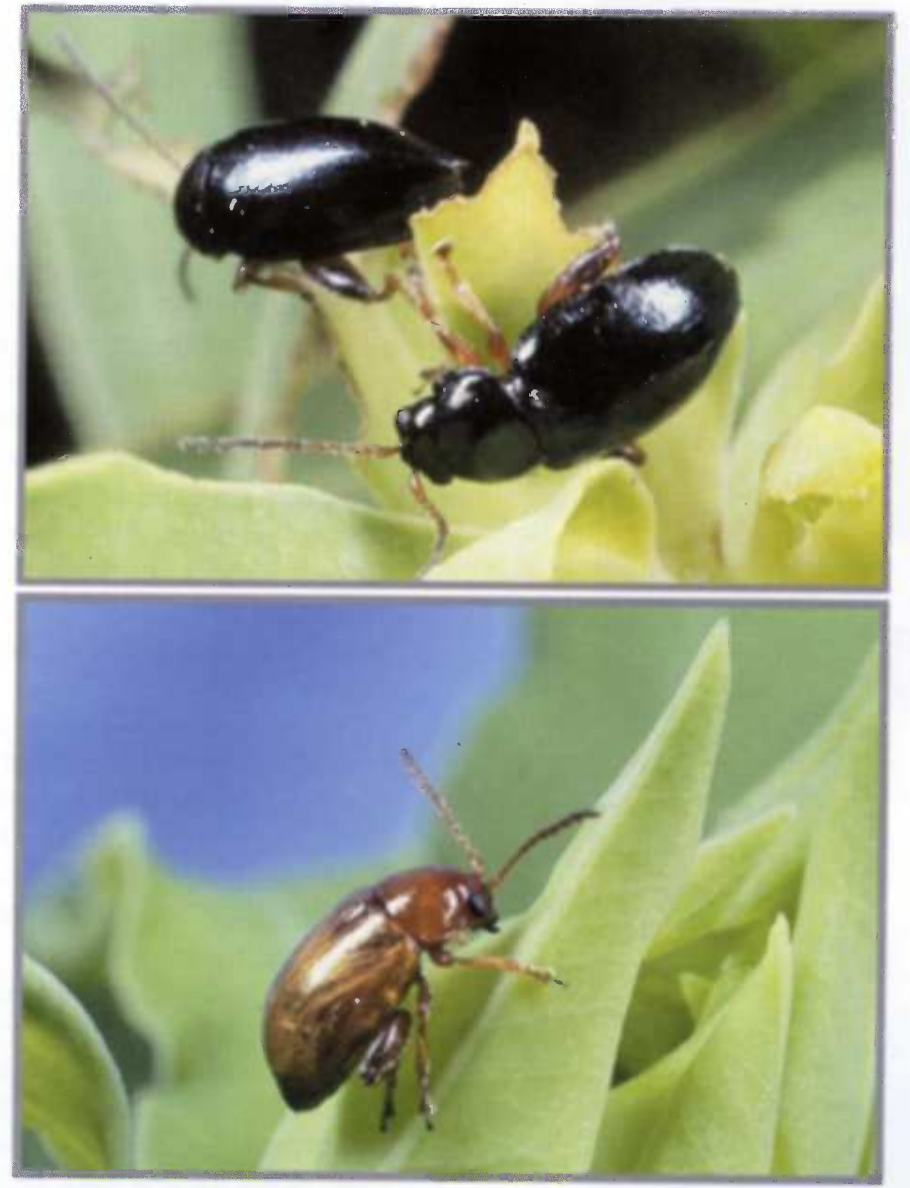

Fig. 2. Top to bottom: Aphthona lacertosa (Black) and A. nigriscutis (Golden Brown).

2000). This leads scientists to believe that control rates will quickly approach and even surpass the rate of leafy spurge establishment as these small resident insect

populations expand to critical density levels and link with other areas where larger insect populations have substantially reduced leafy spurge stem densities.
Based on the above information we conclude that biological control agents have not yet successfully controlled leafy spurge regionally, based on a narrow concept of "success" (Lawton 1985). But control has been established in many local areas, such as hillsides, warm and more open plant communities, and areas where the soils are not too wet or too sandy. Furthermore, the success that has occurred is relatively recent. The first Aphthona species of the leafy spurge biological control program (Aphthona flava) was cleared for release just 15 years ago. The most recent and potentially most effective agent (Aphthona lacertosa) was cleared for release in 1993. The success that leafy spurge biological control has enjoyed is actually quite significant when one considers the large area infested and the huge disparity in time (158 years vs. 15 years) between the introduction of leafy spurge and the introduction of effective biological control agents. While it is premature to label the biological control program a success, current evidence gives us every reason to believe that successful control of leafy spurge in the broad sense is only a matter of time.

\section{Multiple Dimensions of Success}

Some scientists and land managers limit their view of successful weed control to the reduction or elimination of the problem species (biological success). However, other factors that must be con-

\section{Table 2. Leafy Spurge Biological Control Agents.}

\begin{tabular}{llc}
\hline \hline Species and Authority & Order: Family & Date Approved \\
\hline Hyles euphorbia (L.) & Lepidoptera: Sphingidae & 1964 \\
Chamaesphecia empiformis (Esp.) & Lepidoptera: Sesiidae & 1975 \\
Chamaesphecia tenthrediniformis(Den. Sch.) & Lepidoptera: Sesiidae & 1975 \\
Oberea erythrocephala (Schrank) & Coleoptera: Cerambycidae & 1980 \\
Spurgia esulae (Gange) & Diptera: Cecidomyiidae & 1985 \\
Aphthona flava (Guill.) & Coleoptera: Chrysomelidae & 1985 \\
Aphthona cyparissiae (Koch) & Coleoptera: Chrysomelidae & 1986 \\
Aphthona czwalinae (Weise) & Coleoptera: Chrysomelidae & 1987 \\
Aphthona nigriscutis (Foundras) & Coleoptera: Chrysomelidae & 1989 \\
Dasineura sp. Nr. capsulae (Kieffer) & Diptera: Cecidomyiidae & 1991 \\
Aphthona abdominalis (Duftschmid) & Coleoptera: Chrysomelidae & 1993 \\
Aphthona lacertosa (Rosenhauer) & Coleoptera: Chrysomelidae & 1993 \\
Chamaesphecia hungarica (Tomala) & Lepidoptera: Sesiidae & 1993 \\
Chamaesphecia crassicornis (Bartel) & Lepidoptera: Sesiidae & 1996 \\
Spurgia capitigena (Bremi) & Diptera: Cecidomyiidae & 1998 \\
\hline
\end{tabular}




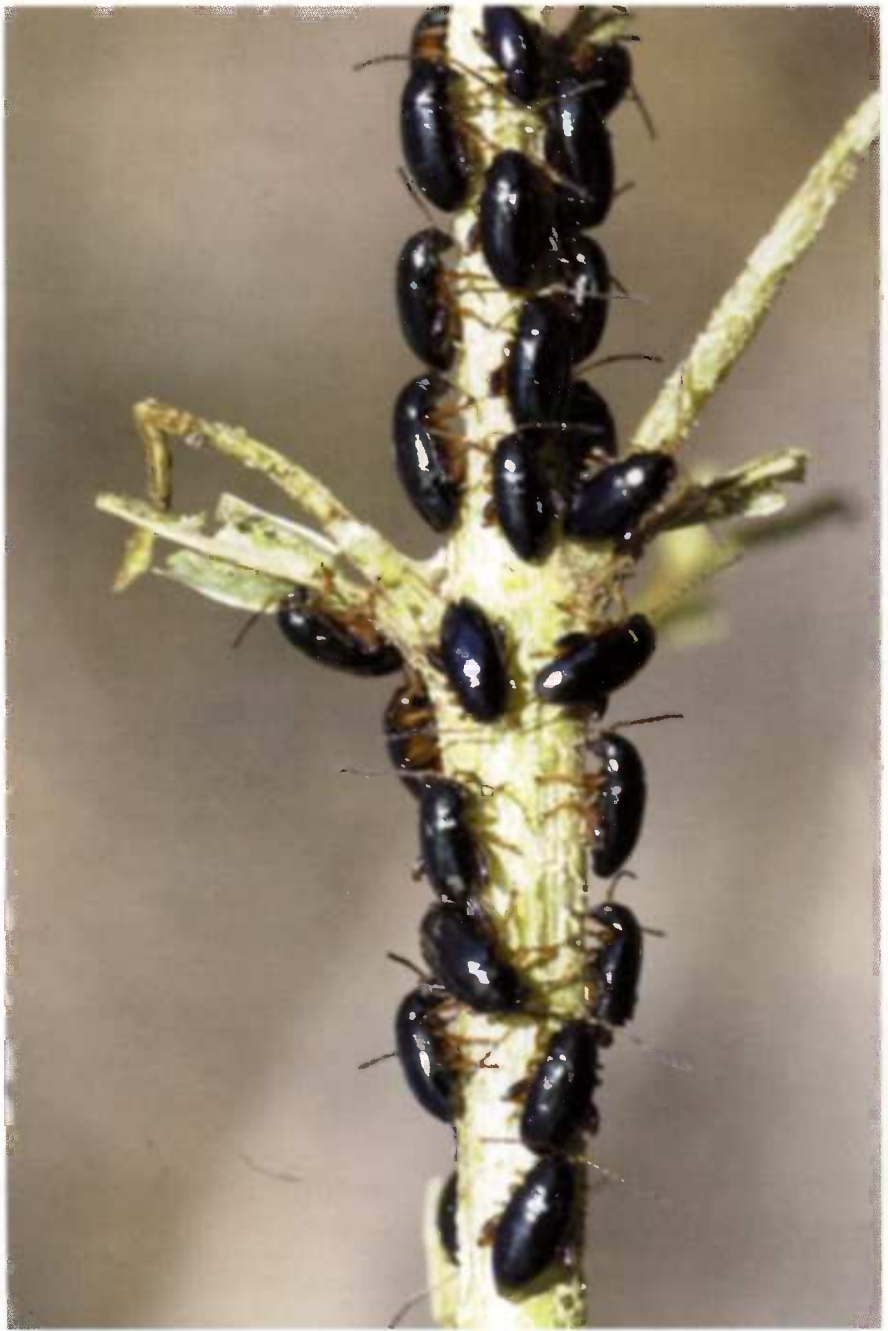

Fig. 3. What's left of a leafy spurge stem covered with Aphthona lacertosa.

sidered include: ecological, scientific, economic, political, social, and legal success. Each component is an integral part of a comprehensive and sustainable weed control effort.

\section{Biological Success:}

What is success? To most ranchers, farmers and weed control specialists, success is getting rid of leafy spurge or at least having less spurge this year than last. One control methodology is biological control. Biological control agents help control leafy spurge in different ways. Primary methods of attack include consumption of above-ground plant material, consumption of root material, and blocking seed production. Aphthona sp. flea beetles have produced the greatest impact on leafy spurge. A. nigriscutis and $A$. czwalinae/lacertosa impact the plant by ovipositing at the base of the plant. The resulting larvae feed on leafy spurge roots, increasing plant morbidity, reducing plant health and creating pathways for the introduction of plant pathogens. We could label this type of success as "botanical or biological success." Biological success is reducing the density of the problem species to the point that it is a manageable part of the landscape. Remember, however, that perspective determines the view of success or failure. We cannot simply associate a reduction in the amount of leafy spurge as a success without considering the impact of the pest and the associated treatment(s) in each success component.

\section{TEAM Leafy Spurge examples:}

Research findings from across the 4 state region of North Dakota, South Dakota, Montana, and Wyoming indicate that managers can realize an $85 \%$ success rate in site establishment of biological control agents and an average rate of control of approximately .65 ha release ${ }^{-1}$ year $^{-1}$
(3,000 Aphthona lacertosa/czwalinae and 3,000 Aphthona nigriscutis released at each site). The release of 6,000 Aphthona spp. at each site was chosen to ensure measurable results over the short 5-year time frame of the project. Operationally, smaller releases of 1,000-2,000 insects released at a greater number of sites can be just as effective (if the sites selected are conducive to insect establishment). In 1998 alone, more than 200 million insects (Aphthona lacertosa/czwalinae) were harvested and redistributed from a single area in North Dakota. If 2,000 insects are released at a site with an establishment success of $85 \%$, then the potential exists for 85,000 new release sites with a rate of leafy spurge control of greater than 55,000 ha year ${ }^{-1}$.

The rate of leafy spurge control using flea beetles is, of course, not constant. As flea beetle populations increase exponentially, so will their impact. One researcher in Montana reported a 7 -fold increase in flea beetles between 1998 and 2000 (Personal Communication, Jack Butler, October 2000). Control in different geographic areas showed reductions in the foliar cover of leafy spurge that ranged from $35 \%$ to $100 \%$. These are substantial reductions considering the insect populations being tracked have only been active for 2 to 3 years. In some older insectaries (areas used to raise harvestable populations of biological control agents) insect populations declined rapidly in 2000 . There was nothing wrong with the insects; they simply had reduced the spurge to a level that would no longer sustain high insect populations. The lesson from 2000 is that flea beetles cannot be taken for granted. We now have large numbers of flea beetles (Fig. 3) spread across a wide geographic area, and they must be managed to start new insectaries to ensure that managers have harvestable flea beetle resources over the upcoming years.

Another form of biological control is the use of herbivores, such as sheep or goats that include leafy spurge as part of their daily food intake (Landgraf et al. 1984) (Fig. 4). Rapid reductions in leafy spurge densities were realized when insect biological control agents were used in combination with sheep. Research on one section of land containing approximately 40-50\% leafy spurge stands with stem counts approaching 200 stems $\mathrm{m}^{-2}$, demonstrated a $31 \%$ to $50 \%$ reduction in leafy spurge stem densities in less than 3 years (Personal Communication, Timothy 


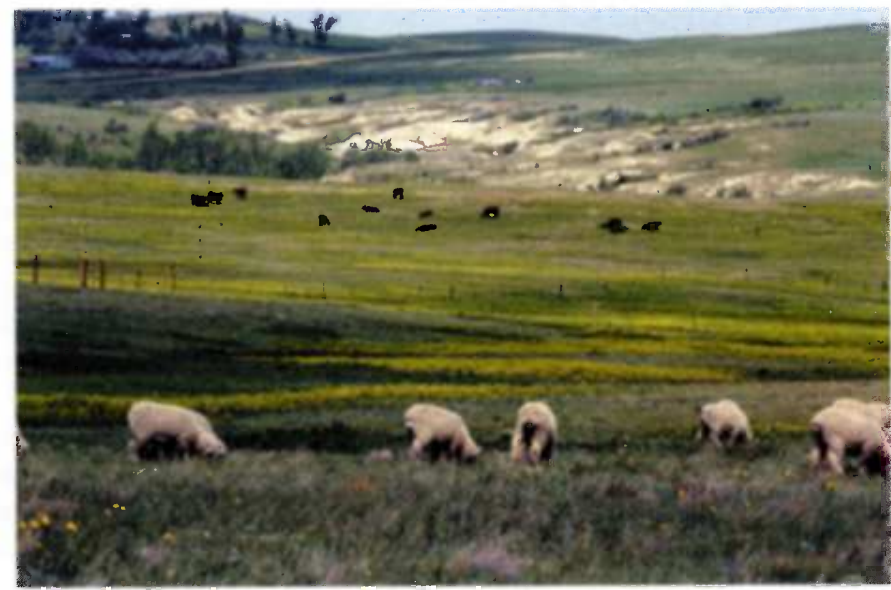

Fig. 4. Multi-species grazing of leafy spurge infested rangeland near Sentinel Butte North Dakota.

Faller, June 2000) (Fig. 5). This research indicates that dense stands of leafy spurge can be rapidly controlled using combinations of sheep and insects. This multispecies scenario may not be feasible in all areas, but it does demonstrate what is possible when multiple pest management tools are used together.

Clearly these observations indicate substantial success in reducing leafy spurge, however, how these sites will respond over time will be a function of the ecosystem and controlling agent dynamics.

\section{Ecological Success:}

Ecological success is a bit more difficult to define. Ideally, the biological control program will impact only the target pest and the indigenous plants will reestablish much as they were prior to the weed's introduction. Unfortunately, most weed infestations and their associated treatments alter some aspect of the ecosystem. An analogy is the use of surgery, chemotherapy, and radiation to treat a cancerous tumor. The tumor is the immediate threat. Left untreated, it will cause irreparable damage or even kill the host organism. The treatments themselves are usually invasive, causing permanent damage to surrounding tissues and organs and sometimes even contribute to the organism's death. How do you define success or failure under these circumstances? It is not as simple as destroying the tumor or eliminating the infestation. For most patients or ecologists, it is the quality of the life they lead or the health of the entire system that is important. Determining what constitutes a quality life or a healthy ecosystem is dependent on the individual or individuals evaluating the circumstances. Therefore, we can conclude that the course of action taken by an individual or group will be based on personal reflection and a qualitative assessment of short-term risks verses long-term gains.

While an ecosystem is not a cognitive organism, the individuals who use and manage these systems are. The decisions they make concerning the use of biological control or other integrated pest management (IPM) strategies are dependent on their perspective, values and aspirations toward the system they are dealing with. From the rancher's perspective, success is the removal of the pest and a subsequent increase in more desirable plant species. Ranch operators are typically not as concerned with the composition of the ecosystem as they are with the quality and quantity of forage available to the operation. Environmental groups are concerned with protecting the quality (health) of the system and its composition (biological diversity). Most federal and state land managers are required to manage the land to maintain or improve productivity and quality and allow for multiple land uses. These differing perspectives often lead to disagreements, protests, and lawsuits (such as against Paterson's curse/salvation Jane, Echium plantagineum, in Australia; Cullen and Delfosse 1985, Delfosse 1985, 1990, Delfosse and Cullen 1985) as each group positions itself to

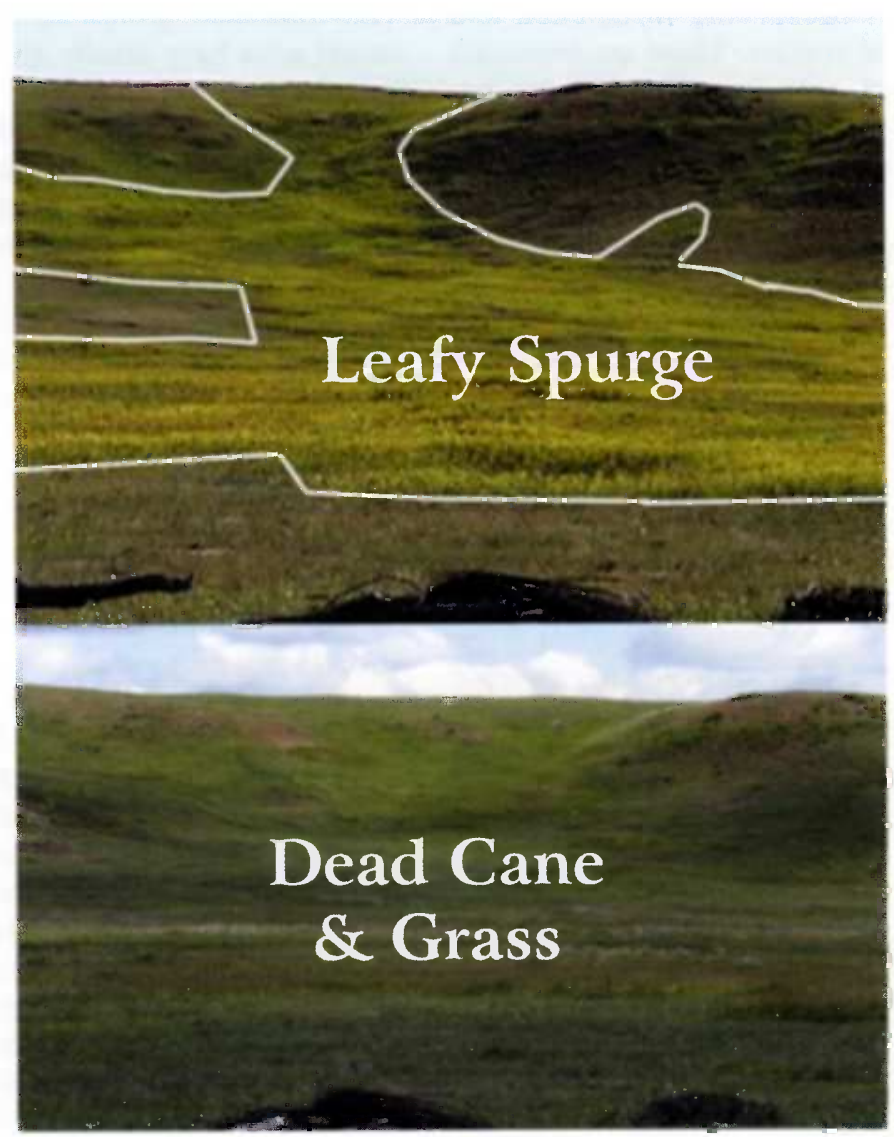

Fig. 5. Before and after photographs of a rangeland draw treated with biologically-based IPM. Multi-species grazing (cattle and sheep) combined with insect biological control agents reduced leafy spurge stem densities across the pasture by $31 \%$ to $50 \%$. 
ensure that its ideologies prevail or that its views are at least considered.

The management guidelines individuals and agencies use on a relatively healthy ecosystem often work together to produce a better system. Unfortunately, as a system deteriorates (e.g., when the condition of a patient worsens or a weed-infestation becomes more pervasive), there comes a point when the rules designed to protect the system (or the individual) can actually interfere with system maintenance and recovery. So it is within this quagmire of emotion, qualitative assessments and conflicting policies that we define exactly what we mean by ecological success. Ecological success is stopping or reversing the progression of an invading pest through the use of biological control agents and other IPM tools that have no direct detrimental effect on the system, or whose negative impacts to the ecosystem are outweighed by the overall benefit of their use. Notice that this definition does not deal with returning the system to some preconceived notion of health, and it ignores issues such as maximizing biodiversity or preserving threatened and endangered species. These are important issues that must be addressed, but are probably more appropriately dealt within the context of post-control rehabilitation.

\section{TEAM Leafy Spurge examples:}

Herbicides are one of the primary tools used to control leafy spurge. The use of herbicides to treat small new stands of leafy spurge and to prevent the spread of larger stands is extremely important; however, repeated use of herbicides over large infestations will reduce the forb component of the community which ultimately has the effect of reducing overall species richness (Butler 1994). Ecological problems associated with herbicides coupled with increasing chemical costs have reduced their use in many areas. Ward County, N.D. (48.5 N, 101.30 W) sprayed approximately 3,200 ha in 1989 . Since then they have reduced herbicide use by 95\% and started an aggressive biological control program. The county distributed over 26 million biological control agents during the summer of 2000 . Observers in the county indicate that spurge stem densities and foliar cover are being significantly reduced without the extensive use of herbicides. Barnes County, N.D. (47.0 N, $98.0 \mathrm{~W}$ ) has reduced their cost of herbicide treatment from $\$ 122,117$ in 1995 to
$\$ 66,400$ in 2000 . As producers and land managers come to realize the potential of biological control, they have elected to reduce their dependence on herbicides. This may not be entirely beneficial since herbicides are needed to control outliers and prevent the leafy spurge perimeter from expanding during the period when biological control agents are developing population numbers sufficient enough to control leafy spurge.

More progressive weed management districts have found the availability of multiple management tools combined with the quick kill capability of herbicides has resulted in more judicious use of chemicals while providing adequate control of the weed. In the summer of 2000 Theodore Roosevelt National Park, Medora, N.D. (46.95 N, 103.4 W), saw large blocks of land where spurge was contained and reduced to acceptable levels by large numbers of insect biological control agents and limited chemical use. As a result, the Park is considering a substantial reduction in the amount of herbicides they will use during the summer of 2001.

Environmental groups and managers of natural areas have usually viewed the use of herbicides to control weed populations as bad for the ecosystem. While there are almost always negative impacts resulting from the use of chemicals, they remain an important tool for slowing the expansion of leafy spurge and sometimes they are the only effective tools available to managers of specific biogeographical regions. Biological control has had limited success in areas dominated by sandy soils. The rooting depth of leafy spurge in sandy areas is substantially deeper than loam/clay soils, therefore, flea beetle larva are not able to penetrate deep enough into the soil to inhabit the fine root hairs they depend upon for food and as over wintering sites (Personal Communication, Don Mundal and Robert Carlson, May 2000). In this case, herbicides provide an essential role in controlling vegetative production and minimizing the dominance of leafy spurge. Regions like the Sheyenne National Grassland near Lisbon, N.D. (46.35 N, 97.3 W) are unique in this respect. They are also unique in that this biotype is home to the western prairie fringed orchid (Platanthera praeclara Sheviak and Bowles). The orchid is a federally listed threatened plant species in the United States. Severe restrictions have been placed on the use of herbicides to control leafy spurge, because of the pres- ence of the orchid. However, the weed itself is more of a problem to the orchid than herbicide treatments. Research indicates that fall herbicide treatments applied over the orchid did not adversely affect orchid growth the following season and there were actually more orchids found in plots treated with herbicides than in untreated plots (Personal Communication, Rodney Lym, June 2000). This is a primary example where conflicting weed treatment and regulatory requirements can interfere with system maintenance and recovery.

Risk assessment must be a part of any comprehensive weed management plan. Leafy spurge crowds out native vegetation, resulting in a monoculture that reduces biodiversity and threatens both abundant and sensitive species. The invasion of exotic weed species in national parks, wildlife refuges and other lands set aside for wildlife and recreation has, in fact, reached epidemic proportions. Dense stands of leafy spurge often have greater than 200 stems $\mathrm{m}^{-2}$ and a foliar cover approaching $100 \%$. The massive root system and long-lasting seed banks continue to present ecological problems even after the aboveground biomass of the weed has been reduced. This is the case in western North Dakota where the canopy cover of leafy spurge has been reduced by as much as $35-40 \%$; however, more than $90 \%$ of the seed bank was made up of undesirable species (Personal Communication, Donald Kirby, June 2000). Research results from Montana and South Dakota indicated even larger reductions in leafy spurge foliar cover, $77 \%$ and $76 \%$ respectively. However, Montana reported increased grass cover $(42 \%)$ and both states realized increased species richness $(27 \%)$ (Personal Communication, Jack Butler, June 2000). Therefore, risk assessment evaluations must be completed in specific regions and under different ecological conditions to determine the best management approach to follow. This type of analysis mandates a basic understanding of the system and how plant communities respond to management.

\section{Scientific Success:}

Another area of success that is often only realized in academia is scientific success. The initiation of a biological control program is often fraught with uncertainty. Successful establishment of an agent in one area does not always translate into success elsewhere. Scientific success is 
the knowledge gained by scientific investigation that improves our understanding of the biological control agent(s), the agent(s) impact on the host plant and what effects the introduction of the agent or changes in the weed population will have on the associated ecosystem. Scientific success helps managers improve the potential of achieving effective control; however scientific success can be achieved independent of biological, ecological, economic, social, political, and legal success. Using the North American leafy spurge control effort as an example of an emerging success story, the program does have several areas where our knowledge base has been expanded. Information concerning the additive or synergistic effects of plant pathogens, alternative grazing programs and limited chemical use with biological control agents helps us to understand how weed control programs can be enhanced by the interaction of multiple control tools (biologically-based IPM). Other research helps us understand the complex ecological interactions (ecological barriers) that can influence the establishment or effectiveness of control agents and other IPM tools on leafy spurge. The fact that several issues remain unanswered, especially in the development of models that can guide the complex ecological and socioeconomic decision-making process, indicates that there is still much to learn. However, the scientific progress made to date is certainly a success upon which others will continue to build.

\section{Economic Success:}

Economic success seems more straightforward than the other concepts we have looked at, but in fact it is just as complex. The traditional view of economic success is for the benefits of the treatment to exceed treatment costs. While this view is certainly true, quantifying treatment benefits resulting from improved ecosystem health and alternative land uses is difficult. The following discussion assumes that weeds must be controlled (i.e. there is no economic threshold below which weed control should not be attempted). Based on this assumption, economic success depends on minimizing costs. To the rancher it is 1 of 3 things: (1) saving on treatment costs and obtaining the same or a better degree of weed control; (2) improving the quality and/or quantity of a marketable commodity; and (3) improving land quality and sustainability (economic value and ecological health). Economic success at the federal, state, or local level includes increased revenue from sales and/or taxes, reduced expenditures for weed control and increased consumer satisfaction and utilization of the land for non-agricultural activities. In general, we can say that economic success is less cash expended for the same or better weed control and/or an increase in the amount of cash returned for every dollar spent on weed control at the local, state, and federal levels. It is generally economic impacts that drive most weed control programs. Unfortunately, the time lag between a weed becoming an ecological problem and its emergence as an economic problem is often decades. This allows the weed to become firmly established, which usually translates into a greater expenditure of resources to achieve control. Perhaps the best alternate definition of economic success is never letting a weed problem reach the level where it has economic impact.

\section{TEAM Leafy Spurge examples:}

The economic impact of leafy spurge is staggering. Infestations in the Dakotas, Montana and Wyoming alone are estimated to cost agricultural producers and taxpayers $\$ 130$ million a year in production losses (Leitch et al. 1994), control expenses and other impacts to the economy. Every AUM (Animal Unit Month) lost to leafy spurge infestations costs $\$ 167$ in lost economic activity. Leitch et al (1994) estimated that the forage loss resulting from leafy spurge infestations could sustain 90,000 additional head of cattle in the 4state region of North Dakota, South Dakota, Montana, and Wyoming.

The cost of controlling leafy spurge with herbicides on 260 ha of land can be overwhelming. If only $40 \%$ of that area were infested with leafy spurge, the standard rate application of Tordon (Picloram) and 2,4-D (2,4-Dichlorophenoxy Acetic Acid) $\left(\$ 31.50 \mathrm{ha}^{-1}\right)$ would cost the rancher or land manager approximately $\$ 3,300$ year $^{-1}$. And, dense population would take a minimum of 10 years to adequately control the leafy spurge and its seeds $(\$ 33,000)$. Most land managers in North Dakota, South Dakota, Wyoming, and Montana depend on agriculture for a living and do not have the resources necessary to sustain a herbicide control program. Therefore, those that choose to use chemical control alone will never control well established leafy spurge infestations.
Viewing the leafy spurge control program with respect to economic success is much the same as evaluating it with respect to ecological success. Control has been established in many local areas, but the total infestation of leafy spurge continues to grow. Exactly how much land is being improved by biological control and other integrated pest management (IPM) technologies is unknown. Therefore, it is difficult to claim that the program has been an economic success, but it has been successful in many local areas. As biological control agents continue to become an integral part of a biologically-based IPM strategy the cost of control (or at least the rate of increased dollars spent to manage the weed) has become less (as seen in Barnes and Ward Counties of North Dakota). Furthermore, as biological control agents continue to have greater impact, the revenue gained from increased production and utilization increases.

\section{Political Success:}

Political success can only be achieved when scientists, community leaders, land managers and special interest groups gain enough support to convince public representatives that it is in the best interest of the state and the country to increase the resources needed to impact the problem. Therefore, political success is effective communication of the problem to customers and stakeholders, such as federal and state representatives, who ultimately enact legislation designed to develop and improve weed management efforts. A major step toward achieving political success was enacted in 1999 with the issuance of the Executive Order \#13112 on Invasive Species. The order establishes an advisory council, mandates agency participation and begins the development of a "National Invasive Species Management Plan." The heightened visibility given to invasive weeds by the Executive Order has definitely been positive, but the success of the initiative depends on the ability of Congress and the administration to directly impact invasive weeds by making more resources available and by implementing changes that improve the efficiency and effectiveness of a national weed control initiative. Landowners and land managers must be proactive in communicating weed issues at the state and federal level to ensure they are not lost among all the other issues. 


\section{Social Success:}

Social success is fairly clear-cut. Here we must consider 2 groups. The land manager is the one directly fighting weed infestations. The tools chosen to address a particular weed problem are often based on previous experience. The adoption of new approaches to the problem are often overlooked or dismissed without much thought. Biological control and biologically-based IPM must be demonstrated, and the land manager's faith in its ability to outperform existing tools must be increased, before the majority will use the approach. Sell et al. (1999) conducted a survey in 9 counties of North Dakota, South Dakota, Montana, and Wyoming. They concluded that the most frequent impediment for using biological control is the view that the agents take too long to work and the perspective that access to biological agents is limited. The same group of respondents indicated that environmental, financial, and educational constraints were the primary reason for not using biologically-based IPM control strategies. Therefore, one component of social success is improving the acceptance of biologically-based IPM strategies by land managers and increasing their willingness to actively search for and obtain the additional resources and expertise needed to address weed problems.

The second group of people that must be considered are those not directly connected to the land. Few individuals in our towns and cities realize the impact noxious weeds have on their lives. During the summers of 2000 and 2001, weeds were determined to be a major contributor to the number and intensity of fires in the western United States with suppression costs totaling $\$ 1.8$ billion (Healy 2001). Therefore, the impact of improper land management can cost everyone millions of dollars, the loss of a home and even threaten lives.

The reality is that public lands are "our lands" even though states and the federal government act as managers. It is in the best interest of citizens to ensure that their lands are being maintained properly. As any facility manager will tell you, it is more cost-effective to constantly maintain and upgrade a facility than to wait and have to fix everything at once. To date, public land managers allocate far too few resources to manage invasive weeds (maintenance). The primary problem is that limited budgets are stretched too thin to adequately address the myriad of prob- lems facing our public lands. Other important issues directly impacting individuals working outside the agricultural community are land values and production returns. A reduced amount of revenue results when weeds invade private and public lands and the value of the land and agricultural income decrease. Revenue also decreases as the money spent on alternate uses decreases [e.g. the estimated annual economic impact of leafy spurge in the 4-state region of North Dakota, South Dakota, Montana, and Wyoming is estimated to be $\$ 130$ million (Leitch et al. 1994)]. This is a substantial amount of money that impacts one of the most economically depressed regions in the United States. The cost to the public is fewer public services, reduced resources and increased taxes (e.g. Montana acquires noxious weed tax revenue through the allocation of a special surcharge on automobile licenses sold in the state). Therefore, the second component of social success is educating the public concerning the problem, their responsibility to the land and the direct impact inadequate management has on their income. Combining the above components, we can define social success as increased awareness of the problem, acceptance of individual responsibility in dealing with the issue, improved understanding of biologically-based IPM and how the different tools are used, and the need for individuals to actively search for and obtain the additional resources and expertise needed to address the issue. Social issues have not been adequately addressed in the past.

\section{TEAM Leafy Spurge preliminary results:}

A major part of TEAM Leafy Spurge is to increase public awareness, demonstrate effective integrated control techniques, and to work directly with ranchers and land managers in implementing current control methodologies. The overall effectiveness of TEAM Leafy Spurge with regard to social success remains to be evaluated; however, the message is getting out. The following quotes were obtained from land managers within the study area:

\section{North Dakota:}

"In the last 3-4 years I have collected and redistributed approximately 6 million flea beetles over 15 sections of rangeland. These 6 million flea beetles are located on approximately 2000 different sites. I have had more success with the flea beetles than we ever did spraying for the past 40-50 years. USDA, TEAM Leafy Spurge just delivered an additional 3 million insects to me last week. I tell my neighbors that within 3-4 years leafy spurge on this ranch will be reduced $85-90 \%$. Where we are standing right now the insects are working and while I am out haying tomorrow the insects will still be working. Biological control for leafy spurge is definitely the way to go." Roger Myers February 2002.

\section{Montana:}

"We had sprayed for many years attempting to control leafy spurge with very limited success. Then Neal Spencer brought us some of the brown flea beetles. The flea beetles have reduced the amount of leafy spurge we once had. Since then TEAM Leafy Spurge has given us some of the black flea beetles that appear to be doing very well. There is no doubt the flea beetles are our only chance at getting rid of leafy spurge." Glen Rugg - June 1999

\section{South Dakota:}

"The ranchers are feeling better about the options they now have against leafy spurge. TEAM Leafy Spurge has been a big plus for area producers. As of 3-4 years ago we knew nothing about biocontrol. We didn't know what to do, let alone how to get massive numbers of flea beetles working on the ground. Along with TEAM Leafy Spurge and the Moreau Weed Management Area, we now have more options. TEAM Leafy Spurge has done a remarkable job in getting the word out about those options. People in this area have now contained the spread of leafy spurge and are now seeing the benefits of a biologically-based IPM approach". Larry Nelson - Nov 2000.

We have started to see some changes in the perspective of individual land managers with respect to biologically-based IPM; however, a great deal of work remains in convincing the general public that it is in their best interest to take a proactive stance on controlling weeds. From the perspective of the Northern Great Plains leafy spurge control effort, social awareness of the problem has been increased among land managers; however, the broad-base societal support needed for social success has not been achieved and additional resources must be committed to garner public support and provide the 
information needed by land managers to address the problem.

\section{Legal Success: \\ Legal success is the enactment of laws that prevent the introduction of invasive species, mandate effective control pro- grams (e.g. biological control) and assess substantial penalties for failure to comply with existing laws. Many states have enacted laws designed to limit the spread and mandate the treatment of leafy spurge and other noxious weed populations, but most lack sufficient legal penalties to ensure compliance. In this instance, state and federal programs have not achieved the legal success needed to support the leafy spurge control program. \\ The TEAM Leafy Spurge has not been a part of the legislative process. We view our part as an information source that law- makers can use to enact the legislation needed to manage noxious weeds and ulti- mately contribute to the control of noxious weed problems in their area. The effec- tiveness of the legislation enacted depends on a clear understanding of the problem and its implications. Unfortunately, the laws enacted are often clouded by politics. Therefore, broad-based political support is essential and can only be achieved by addressing the problem in each of the major thrust areas listed above. Only then will all the components needed for effec- tive weed management be in place.}

\section{Conclusions}

Leafy spurge has been in the United States for a long time and it will never go away. The best we can hope to do is reduce its impact below ecologically and economically significant levels. There is no one tool adequate to deal with the massive infestations currently plaguing the United States and Canada; however we believe that biologically-based integrated pest management (IPM) offers the best scenario of achieving the desired control level. Has biological control or biologically-based IPM been successful in controlling leafy spurge? The answer depends upon your perspective. Scientifically and politically, the northern Great Plains leafy spurge effort has made significant progress and we believe each can be considered a success, even though a great deal of additional work is still needed. On the national scale, host specific flea beetles

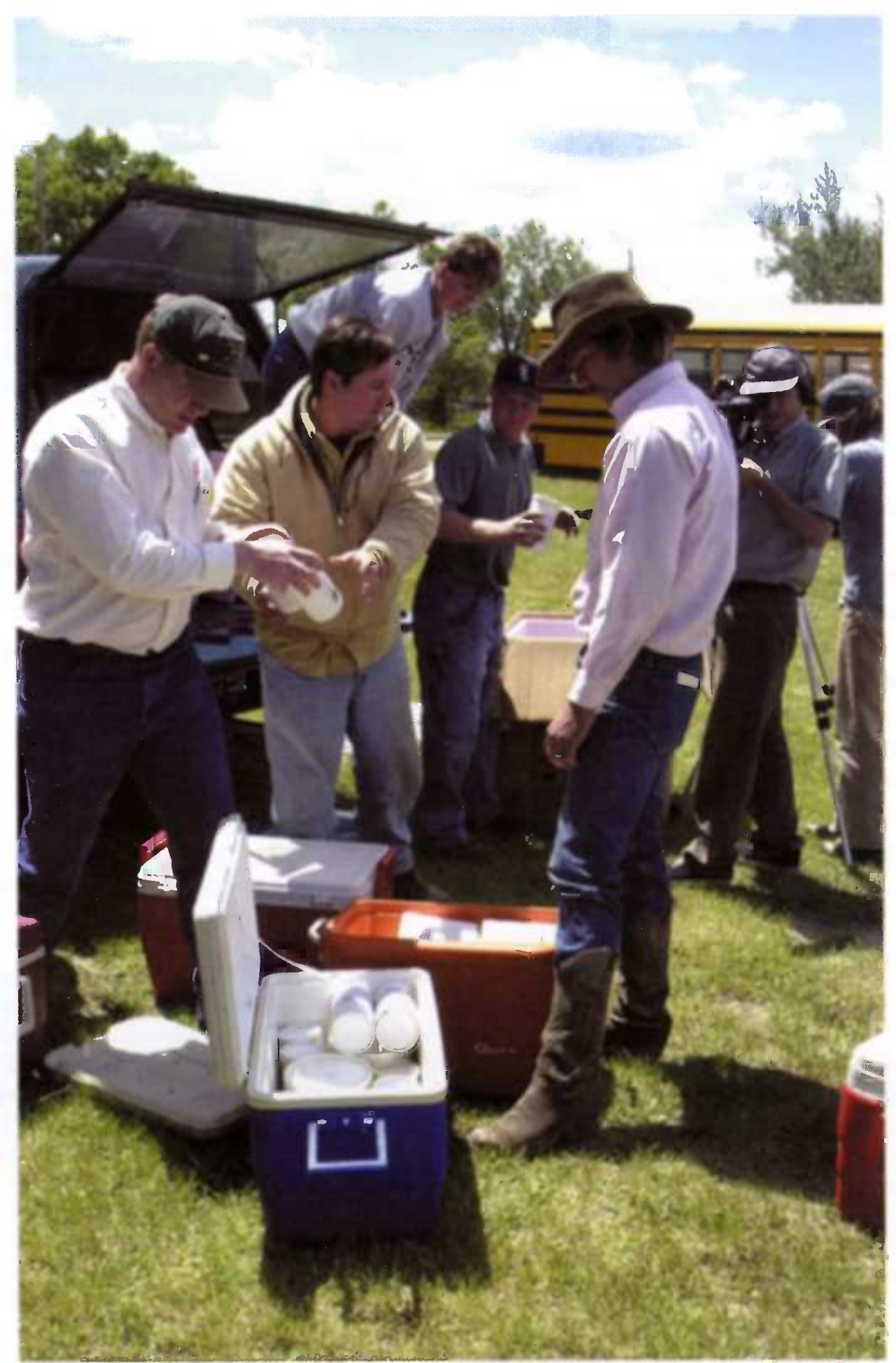

Fig. 6. Federal, state and private land managers working together at the Ekalaka, Montana Range Days (June 2000) to distribute biological control agents throughout the region.

have been collected and moved to many new areas where biological control agents have never been used. Land managers have seen the impacts of biocontrol agents and embraced their use, which has simultaneously reduced their reliance on herbicides and other more expensive control methods. The continued increase and spread of biocontrol agents coupled with a decline in leafy spurge populations, strengthens the interest and support for biologically-based IPM strategies. Success in the biological, ecological, and economic thrust areas has been demonstrated at many sites across the northern Great Plains. Additional work is needed to educate land managers and the public concerning the best methods of treating the problem, the need for proactively augmenting and managing their biological control agents and allowing additional time for biological control populations to expand and coalesce across regions. Similar progress in the control of other weed species such as spotted knapweed (Centaurea biebersteinii DC.), yellow starthistle (Centaurea solstitialis L.), melaleuca [Melaleuca quinquenervia (Cav.) T. Blake], and salt cedar (Tamarix ramosissima Ledeb.) will continue to strengthen the concept of biologicallybased IPM. Two problem areas where weed control efforts has been relatively ineffective are the social and legal components of the program. A greater emphasis must be placed on public and land manag- 
er education, as well as enacting laws that provide significant incentives for public compliance.

The northern Great Plains leafy spurge control effort has contributed a great deal to our understanding of the weed and how it will be controlled in the future. It is important that we acknowledge the contribution of all individuals who have spent their careers, and in some cases their lives, putting in place the control infrastructure we have today. The momentum toward effective management of leafy spurge has rapidly increased because of their efforts. Successful biologically-based leafy spurge control is on the horizon, especially when weed managers understand the number of problem areas (biological, ecological, scientific, political, social, and legal) that must be addressed to achieve a sustained reduction of a weed population. The amount of time it will take to be realized depends on our commitment to solving the problem and our willingness to work together as a cohesive team (Fig. 6).

\section{Literature Cited}

Anderson, G.L., CW. Prosser, S. Hager, and B. Foster. 1999. Change detection of leafy spurge (Euphorbia esula) infestations using aerial photography and GIS. Proc.. of the $17^{\text {th }}$ Biennial Workshop on Color Photography \& Videography in Resource Assess. pp. 223-230

Bangsund, D.A. and F.L. Leistritz. 1991. Economic impacts of leafy spurge on grazing lands in the Northern Great Plains. Agr. Econ. Rep. No. 275-S. North Dakota State University, Fargo, N.D.

Britton, N.L. 1921. The leafy spurge becoming a pest. J. N.Y Bot. Gard. 22:73-75

Butler, J. L. 1994. The effects of herbicide treatment on leafy spurge and non-target species. In: Proc. Leafy Spurge Strategic Planning Workshop, 29-30 March, Dickinson, N.D.

Cullen, J.M. and E.S. Delfosse. 1985. Echium plantagineum: Catalyst for conflict and change in Australia. pp. 249-92 In: Delfosse, E.S. (ed.) Proc. of the VI Internat. Symp. on Biol. Control of Weeds, 19-25 August 1984, Vancouver, British Columbia.

Delfosse, E.S. 1985. Echium plantagineum in Australia: Effects of a major conflict of interest. pp. 293-299 In: Delfosse, E.S. (ed.), Proc. of the VI Internat. Symp. on Biol. Control of Weeds, 19-25 August 1984, Vancouver, British Columbia.
Delfosse, E.S. and J.M. Cullen. 1985. The CSIRO Division of Entomology submissions to the Industries Assistance Commission and Biological Control Authority Inquiries into Biological Control of Echium plantagineum L. Plant Prot. Quart. 1(1):24-40.

Delfosse, E.S. 1990. Echium in Australia: The conflict continues. Abstract. p. 117. In: Delfosse, E.S. (ed.), Proc. of the VI Internat. Symp. on Biol. Control of Weeds, 6-11 March 1988, Rome, Italy. Istituto Sperimentale per la Patologia Vegetale Ministero dell'Agricolture e delle Foreste, Rome, Italy.

Dunn, P.H. 1979. The distribution of Leafy Spurge (Euphorbia esula) and other weedy Euphorbia spp. in the United States. Weed Sci. 27: 509-516.

Galitz, D.S. 1980. A summary of the synonymy of leafy spurge. ND Res. Rep. No. 77 July 1980.

Gassmann, A. 1996. Classical biological control of weeds with insects: A case for emphasizing agent demography. pp. 171-175. In: V.C. Moran and J. H. Hoffmann (eds.), Proc. of the IX Internat. Symp. on Biol. Control of Weeds, 19-26 January 1996, Stellenbosch, So. Africa. University of Cape Town.

Healy, C. 2001. Drought fuels loss of U.S. western land to invasive grass and wildfires. "EarthPulse" National Geographic News, June 28, 2001. Electronic Publication

Krebs, C.J. 1978. Applied problems II: Biological control. Ecology: The Experimental Analysis of Distribution and Abundance (Second Edition) pp. 355-369 Jeffrey K. Smith and Eleanor Castellano (Ed), Harper and Row, New York.

Landgraf, B., P.K. Fay, and K.M. Havstad. 1984. Utilization of leafy spurge by sheep. Weed Sci. 32(3):348-352

Lawton, John H. 1985. Ecological theory and choice of biological control agents. Agric Can., pp. 13-26. In: Delfosse, E.S. (ed.), Proc. of the IX Internat. Symp. on Biol. Control of Weeds, 19-25 August 1984, Vancouver, Canada.

Leitch, J.A., D.A. Bangsund, and F.L. Leistritz. 1994. Economic effects of leafy spurge in the upper Great Plains: Methods, models, results. Agr. Econ. Rep No. 316. Fargo, N.D: North Dakota State Univ. Dept. of Agr. Econ.

Noble, D.L., P.H. Dunn, and L.A. Andres. 1979. The leafy spurge problem. In: Proc. Leafy Spurge Symposium. Bismarck, N.D. 26-27 June pp. 8-15.

Nowierski, Robert M. 1985. A new era of biological weed control in the western United States. pp. 811-815. In: Delfosse, E.S. (ed.).Proc. of the VI Internat. Symp. on Biol. Control of Weeds, 19-25 August 1984, Vancouver, Canada. Agr. Can.,

Quimby, Jr., P.C. and L. Wendel. 1997. The ecological area-wide management (TEAM) Leafy Spurge. pp. 51. In: Executive Summary, USDA, ARS, Wide Area funding proposal, Sidney, Mont.
Sell, R.S., D.A. Bangsund, and L.F. Leistritz, 1999. Euphorbia esula: Perceptions by ranchers and land managers. Weed Sci. 47:740-749.

Selleck, G. W., R.T. Coupland, and C. Frankton, 1962. Leafy spurge in Saskatchewan. Ecol. Monographs 32:1-29.

Sterling, J.J., G. Lym, and D.R. Kirby. 2000. Response of the prairie fringed orchid to herbicides for leafy spurge control. Proc. West. Soc. Weed Sci. 53:207-209.

Stevens, O.A. 1963. Handbook of North Dakota Plants. North Dakota Institute of Regional Studies. Page 197. North Dakota Institute for Regional Studies, Fargo, 324 p.

Trammell, M.A. and J.L. Butler. 1995. Effects of exotic plants on habitat utilization by native ungulates. J. Wildl. Manage. 59:808-816. 